\title{
ethic@ \\ NOTA SOBRE A NATUREZA DA MULHER NA COMUNIDADE FAMILIAR E POLÍTICA SEGUNDO PLATÃo, ARISTÓTELES E HEGEL ${ }^{1}$
}

\author{
SOME REMARKS ON WOMAN'S NATURE IN THE FAMILY AND POLITICAL \\ COMMUNITY ACCORDING TO PLATO, ARISTOTLE AND HEGEL
}

\author{
MARINA DOS SANTOS ${ }^{2}$ \\ (Universidade Federal de Santa Catarina, Brasil)
}

\begin{abstract}
RESUMO
Este artigo pretende mapear, comparativamente, o lugar destinado à mulher no interior dos sistemas políticos de Platão, Aristóteles e Hegel a partir de um breve esboço de suas concepções sobre a natureza humana e a natureza feminina. Pretender-se-á indicar em que medida há uma relação, ora de tensão, ora de complementaridade, no modo como elementos descritivos e prescritivos operam para circunscrever o espaço da mulher à esfera privada do lar, no caso das perspectivas aristotélica e hegeliana, e como a subordinação de elementos descritivos a elementos prescritivos permitem que a mulher ascenda à esfera pública sob a perspectiva platônica. Após traçar esse esboço, buscar-se-á sugerir como essa tensão, no caso da filosofia política de Hegel, resultará, por um lado, numa explícita negação dos direitos políticos da mulher e, por outro, na possibilidade de vislumbrar a igualdade civil e política entre homens e mulheres a partir de um dispositivo interno e inerente ao sistema hegeliano, a saber, a noção de "segunda natureza" como reposição ética do natural.
\end{abstract}

Palavras-chave: Natureza humana. Mulher. Família. Comunidade política. Eticidade.

\begin{abstract}
The aim of this paper is to examine, comparatively, women's place within the political systems of Plato, Aristotle and Hegel from a brief sketch of their conceptions about human nature and feminine nature. It will be intended to indicate to what extent there is a relation, sometimes of tension, sometimes of complementarity, in the way descriptive and prescriptive elements function to circumscribe the space of women from the household private sphere, from Aristotelian and Hegelian perspectives, and how the subordination of descriptive elements to prescriptive elements allow woman to ascend in the public sphere under the Platonic perspective. After tracing this sketch, it will be suggested how this tension, in the political philosophy of Hegel, will result, in a way, in an explicit denial of women's political rights and, in another way, in the possibility of envisioning civil and political equality between men and women from an internal and inherent device of the Hegelian system, the notion of "second nature" as ethical reposition of the natural.
\end{abstract}

Keywords: Human nature. Woman. Family. Political community. Ethical life. 


\section{Introdução}

O objetivo do presente artigo é traçar um breve esboço sobre o lugar destinado à mulher no interior dos sistemas políticos de Platão, Aristóteles e Hegel e tentar achar espaço, dentro da teoria deste último, para vislumbrar a possibilidade da equidade civil e política entre mulheres e homens através da noção de vida ética como segunda natureza. A marca desses sistemas filosóficos, como pretenderemos mostrar, consiste na postulação que a natureza humana possui características essenciais, as quais não podem ser totalmente satisfeitas pelas mulheres. Tal marca funda-se sobre a crença que o ser humano e a mulher possuem características que lhe pertencem de necessidade e que a mulher, dada a sua natureza essencialmente determinada, não é capaz de satisfazer plenamente os requisitos da natureza humana.

Pretender-se-á mostrar, primeiramente, como, para Platão, conceder à mulher a mesma educação concedida ao varão da comunidade dos guardiões da pólis, em vez de mantê-la em condições totalmente aculturais, é condição sine qua non para a realização da pólis ideal. Tais concessões que Platão pretendia fazer ao sexo feminino, como veremos, não tornam Platão um "feminista", pois de nenhum modo o filósofo ateniense parece defender a tese que as mulheres são iguais aos homens em virtudes intelectuais ou morais ou que elas possam preencher os requisitos necessários e suficientes para a satisfação do ideal da natureza humana.

Nessa mesma linha, porém, extraindo consequências mais cerceadoras e opressivas que as platônicas, podemos localizar a visão aristotélica sobre o papel da mulher. Segundo o Estagirita, como veremos, a mulher é inferior ao homem sob o aspecto biológico, anímico (ou psicológico) e ontológico, o que "legitima", aos olhos do Filósofo, a exclusão feminina do âmbito político, já que essa esfera está fundada sobre o governo da racionalidade e das virtudes intelectuais, as quais o sexo feminino é naturalmente inapto a comportar e, por isso, a mulher não é plenamente digna da condição de cidadã da pólis.

Hegel, por sua vez, parece sustentar uma posição sobre a natureza feminina bastante próxima de Aristóteles, distanciando-se, assim, de Platão, visto que, segundo Hegel, a determinação substancial da mulher dá-se no âmbito da família, pois é próprio da natureza do caráter feminino não se comportar segundo as exigências da universalidade, mas segundo opiniões e inclinações contingentes engendradas pela fragilidade característica do sentimento, a qual deve ser eliminada no processo de desdobramento do conceito de eticidade para que a 
realização plena da ideia da liberdade se dê. No entanto, mesmo que a letra do próprio texto de Hegel pareça tão contrária à igualdade civil e política entre homens e mulheres, a noção de vida ética como segunda natureza permite, como pretender-se-á mostrar, vislumbrar a possibilidade da equidade de direitos e deveres civis e políticos entre os sexos através da reposição ética daquilo que é meramente sensível e natural mediante o engendramento de costumes que superem tais elementos contingentes, conduzindo, assim, àquilo que é universal e necessário.

\section{A educação e o papel da mulher na comunidade dos guardiões da pólis ideal de Platão:}

\section{República $^{3}$ V 449a-457c}

A partir de 449a, Platão aborda a questão da educação das mulheres e das crianças pertencentes à comunidade dos guardiões da pólis (minoria dominante chamada a defender a comunidade política), delineando, assim, o papel que tal questão representa na configuração do seu Estado ideal. Tal discussão centrar-se-á em determinar o regime mais adequado a ser adotado para a formação das mulheres e da prole dessa comunidade, visto que tal formação "arrastará consigo alterações grandes e até radicais, conforme for bem ou mal realizada", conforme $449 \mathrm{~d} 5-6$.

O fato de chamar mulheres a defender a pólis, provendo-as, assim, do título de guardiãs, já coloca Platão numa situação embaraçosa frente à opinião sustentada pelo senso comum acerca da mulher, visto que a marca da situação do sexo feminino em Atenas, por exemplo, é a da marginalidade e da passividade que o submetem à incultura física e intelectual. Tendo isso em vista, a defesa da tese que é preciso conceder às mulheres a mesma educação dispensada aos varões da comunidade dos guardiões é um embaraço ainda maior para Platão, pois tal tese confronta radicalmente os costumes vigentes em Atenas e o modo como o fenômeno do comportamento moral feminino era observado. Assim, é revisando e se afastando do modo empiricamente dado e constatável do comportamento da mulher que a teoria platônica não pretende tão somente descrever a realidade sensível, mas prescrever uma nova realidade de acordo com o necessário desenvolvimento lógico da ideia de pólis. Isso talvez explique o rodeio que Sócrates tece, no início do livro $\mathrm{V}$, antes de expor tese tão arrojada, a qual ele teme ser ridicularizada por aqueles que "colhem imaturo o fruto da sabedoria" (citação de Píndaro que ocorre em $457 \mathrm{~b} 3^{4}$ ) e que só é trazida à baila depois de reiteradas exortações dos interlocutores socráticos que prometem considerá-la com sabedoria 
e credulidade.

O primeiro argumento introduzido por Sócrates é de que em todos os casos em que se exige de indivíduos de uma mesma espécie, mas de sexos diferentes, que exerçam atividades idênticas, faz-se necessário conceder a eles a mesma criação e educação. Aplicando tal regra ao caso da classe guardiã, infere-se, necessariamente, que as mulheres, devendo cumprir as mesmas funções que os varões, têm de receber a mesma educação concedida a eles, isto é, têm de ser educadas na ginástica, na música e na arte bélica. Sobre essa inferência incide a questão de saber como é possível designar as mesmas funções a seres de naturezas diferentes como parece ser o caso de homens e mulheres, já que, como já foi estabelecido anteriormente, a justiça consiste em designar a naturezas iguais, funções iguais e a diferentes, funções diferentes. A estratégia utilizada por Platão para responder a tal questão consistirá em esclarecer que a diferença sexual não é tão profunda e essencial a ponto de interferir negativamente na realização das funções e dos deveres de guardiões do mesmo modo como, por exemplo, não é possível afirmar que um homem que tenha cabelo em abundância e outro que sofra de calvície não possam realizar a função de sapateiro por possuírem naturezas (capilares) diferentes. Platão prossegue afirmando que o que impede indivíduos de exercerem uma mesma função é o fato de uns possuírem aptidão para exercê-la e outros não, mas tal restrição é imposta pelas diferentes aptidões naturais ${ }^{5}$ que cada indivíduo possui e não pela diferença sexual. Assim, o único justo critério que impede uma mulher de exercer as funções e deveres de guardiã é a falta de uma natural aptidão para isso e não, simplesmente, por não ser do sexo masculino, ou seja, as diferenças constitutivas de cada sexo não são relevantes para que o exercício gímnico, musical e bélico possa ou não ser realizado de modo perfeito. Platão, prevendo a ridicularização da qual será vítima tal tese em virtude de ser tão contrária aos costumes de sua época, aduz o argumento que, à luz da razão, muitas práticas que pareciam, à primeira vista, ridículas foram reveladas como o que havia de melhor a ser feito.

Nota-se, então, que a educação das mulheres é implicada de modo necessário pelo sistema concebido por Platão da comunidade dos guardiões, pois, se a função desta elite dominante é defender a pólis e, para que isso seja feito de modo perfeito, é preciso que essa classe seja constituída pelos melhores indivíduos, então, as mulheres guardiãs também terão de ser as melhores dentre as demais mulheres e, desse modo, poder-se-iam gerar, a partir desses melhores, outros guardiões, aprimorando assim a raça dessa classe. Tal aprimoramento, aos olhos de Platão, dá maior legitimidade ao governo dos guardiões sobre os seus governados. 
Deixando em segundo plano as teses eugenistas e autoritárias que vêm de contrabando com a defesa da tese da educação das mulheres pertencentes à comunidade dos guardiões, gostaríamos de ressaltar um outro aspecto, esse, sim, filosoficamente relevante, implicado pela defesa da tese da formação feminina, a saber, a abolição da vida familiar e da propriedade privada, pois, segundo Platão, tais elementos constituiriam um entrave à dedicação total e incondicionada ao bem coletivo, a qual é exigida pelo cumprimento perfeito da função de guardião da pólis. Ora, não havendo varões dotados de propriedade e de vida privada, não será possível que cada um deles governe uma família e, portanto, tenha mulher e filhos sob seu comando nem nutra interesses egoístas. A supressão das preocupações ligadas à vida familiar particular é o que permite aos guardiões da pólis dedicarem-se incondicionalmente à busca e defesa do bem comum, o que, segundo Platão, é condição de possibilidade para o estabelecimento duma unidade absoluta do corpo político. É interessante notar como Platão parece antever uma preocupação filosófica que será cara à filosofia política moderna e contemporânea, a saber, como compreender a natureza e a subordinação existente entre as esferas pública e privada bem como os papéis atribuídos a homens e mulheres, nessas esferas, através da adoção do critério do sexo ou do gênero, sejam eles compreendidos como naturais ou como construtos sociais. Ao suprimir a propriedade privada e a instituição familiar (concebida como uma célula privada, no interior da comunidade política, portadora de um papel desviante em relação à perseguição e realização do interesse público) e ao delegar à classe dos artesãos e agricultores o cultivo de alimentos e a produção de artefatos necessários à satisfação das necessidades básicas, Platão consegue alçar a mulher pertencente à classe dos guardiões à esfera pública.

Deve-se observar, então, que as concessões que Platão pretendia fazer ao sexo feminino não consistem em benevolência nem simpatia pessoal, as quais Platão poderia nutrir contingentemente pelas mulheres, mas, sim, que tais concessões são uma consequência necessária do modelo de formação dos guardiões requerido pela efetivação da pólis ideal. Parece claro, assim, que a defesa de tal tese não nos permite imputar a Platão o título de precursor da defesa da tese da igualdade, sem qualificação, entre os sexos, nem no reconhecimento da mulher como detentora, tal como o homem, de iguais direitos-deveres, virtudes e dignidade fundados sobre uma concepção paradigmática da natureza humana que a mulher é capaz de satisfazer. Em nenhum momento, pois, a letra do texto do próprio filósofo, permite-nos sequer inferir que as mulheres possam ser consideradas iguais aos homens em inteligência, caráter e entendimento, mas, pelo contrário, poderíamos ter a letra do texto 
contra nós como é o caso das passagens $431 \mathrm{~b}-\mathrm{c}^{6}, 469 \mathrm{~d}^{7}, 557 \mathrm{c}^{8}, 563 \mathrm{~b}-\mathrm{d}^{9}$. Nesse sentido, "o feminismo platônico" não pode ser explicado em termos de uma primeira tentativa de suprimir integralmente a base da opressão feminina fundada numa concepção paradigmática de natureza humana, a qual a mulher não poderia satisfazer, mas é, sobretudo, uma consequência necessária de sua concepção política sobre a comunidade ideal, a qual exige a igualdade de formação entre varões e mulheres no interior da classe dos guardiões. Assim, educar as mulheres não é uma finalidade ou bem intrínseco, dentro da perspectiva teórica do platonismo, mas uma condição sine qua non do desenvolvimento lógico da Ideia de Pólis.

É interessante notar que os sistemas de filosofia política modernos e contemporâneos necessitarão de seus maiores esforços e enfrentarão grandes desafios para compreender, descrever, criticar e prescrever qual o papel da mulher no interior da família, do mercado de trabalho, da sociedade civil e do Estado. Serão tais sistemas capazes, sem prescrever a supressão da propriedade privada e da família nem tornar a realização das ações políticas e tarefas produtivas excludentes entre si, de compatibilizar os papéis que a mulher desempenha nesses diferentes meios e, ainda assim, garantir sua ativa participação na esfera pública como fizera Platão? Parece-nos que caberá à filosofia política debruçar-se incansavelmente sobre as condições e as bases da opressão da mulher que lhe impede de constituir-se como sujeito de sua autonomia e de atualizar seus potenciais emancipatórios no interior de cada uma dessas instâncias, pois, sem isso, a pretensão mesma de universalidade da categoria de autonomia do sujeito estaria fadada ao fracasso. Assim sendo, se o início da era contemporânea é marcado pela inserção massiva da mão de obra feminina no mercado de trabalho, a filosofia política contemporânea não poderá escapar ao desafio de responder pela possibilidade ou impossibilidade da compatibilização entre as demandas da reprodução biológica, ligada à natalidade e à preservação da espécie e da família, e da produção de alto rendimento, ligada ao mercado de trabalho, dado o atual estágio de desenvolvimento do modo capitalista de produção, o qual não pode dispensar a mão de obra feminina e, ao mesmo tempo, impõe severos limites às políticas de ação do Estado de bem estar social que poderia vir a viabilizar uma inserção sustentável da mulher no mercado de trabalho diante de sua tripla jornada, a saber, a criação dos filhos, a conservação da casa e a produção do trabalho. 


\section{A submissão da mulher no sistema político de Aristóteles e sua suposta legitimação sob os aspectos biológico, anímico e ontológico}

Aristóteles crê, dentro dos limites de uma visão segundo a qual a estrutura das relações mantidas no interior da família e da comunidade política repercutem as relações fundadas na "natureza" (physis), que a inferioridade da mulher em relação ao varão, o que a exclui da participação na vida política e a impede de alcançar uma vida plenamente feliz, possui sustentação a partir da articulação de teses de cunho biológico e psicológico, as quais, por sua vez, fundam-se, em última instância, sobre pressupostos de caráter ontológico.

O papel da mulher no sistema político de Aristóteles é trazido à baila quando o Estagirita opera, em Politica $^{10}$ I, a descrição dos três tipos de relações constitutivas da família e da casa e que, segundo ele, engendram-se naturalmente, a saber: i) a relação entre marido e mulher: tal união dá-se em função do instinto natural de reprodução, que está presente em todos os seres naturais animados, dado que todos esses seres "o mais natural dos atos é produzir outro ser igual a si mesmo; o animal, um animal. a planta, uma planta, a fim de que participem do eterno e do divino como podem; pois todos desejam isto e em vista disto fazem tudo o que fazem por natureza", De Anima ${ }^{11}$ II 4 415a28-b2 ou, de acordo com Política I 2 1252a27-30, o instinto de preservação da espécie é inerente e natural ao homem, assim como o é em todos os outros seres naturais animados; ii) a relação entre senhor e escravo: a qual também é natural, pois aquele que é capaz de bem deliberar e agir de acordo com aquilo que foi posto pela boa deliberação é senhor e mestre por natureza, enquanto aquele que dispõe apenas de força corporal para executar tais coisas, antevistas pelo senhor, é naturalmente escravo; iii) relação entre pai e filhos: tal relação é marcada pelo domínio monárquico do pai sobre os filhos em função do respeito e do amor à idade paterna, a qual, segundo Aristóteles, é, no mais das vezes, sinônimo de sabedoria.

Todas essas três espécies de relação familiar pertencem à esfera da vida privada, ou seja, dizem respeito ao domínio da casa e não, ainda, da pólis. O varão só possuirá uma segunda espécie de vida, a vida política, quando do surgimento da pólis ${ }^{12}$. O poder de administração da casa, através da dominação sobre a mulher, os escravos e os filhos deve ser do varão que é, respectivamente, marido, senhor e pai. A justificação aristotélica do porquê isso deve ser assim baseia-se na afirmação de que a constituição psicológica (anímica) dos escravos, da mulher e dos filhos, impele-os naturalmente à subordinação. No caso, pois, da relação senhor-escravo, um naturalmente é talhado ao comando (uma vez que é detentor da capacidade de bem deliberar e agir de acordo com o que foi posto pela deliberação) enquanto 
o outro o é a obedecer (uma vez que não possui a capacidade de deliberar, mas apenas possui força física para a execução das tarefas deliberadas pelo senhor). Isso é assim, segundo Aristóteles, visto que, no escravo, a parte irracional da alma (constituída pela função vegetativo-reprodutiva e pelo desejo irracional) suplanta a parte racional da alma (constituída pela razão, a qual consistirá no princípio racional prático que operará no interior das virtudes morais e será responsável pela deliberação e pela escolha deliberada, conforme a divisão da alma apresentada em Ética Nicomaqueia I 13 1102a27-1103a10). Aristóteles crê que a faculdade deliberativa encontra-se ausente do escravo, de modo a torná-lo naturalmente inferior ao senhor e subordinado a este, pois não possui as condições exigidas para a plena realização da função humana que é fazer tudo com razão, ou, pelo menos, não sem razão. Por isso, ele necessita, por questões de sobrevivência, estar sob o jugo do senhor, pois, por si só, o escravo não pode manter-se, dado que o escravo é análogo ${ }^{13}$ a parte irracional da alma (neste caso, da família), isto é, o escravo tem de ser capaz de obedecer naturalmente à parte racional da família, a saber, o senhor. A mulher, por seu turno, difere do escravo, não apenas por ela ser livre, enquanto o escravo é propriedade do senhor, mas também porque a faculdade deliberativa está presente nela, mas, segundo Aristóteles, é inoperante na medida em que a mulher não consegue agir de acordo com aquilo que delibera, pois há sobreposição do desejo sensível sobre o objeto racional do querer. Se a razão, no sexo feminino, não é operativa, isto quer dizer que as mulheres são incapazes de possuir virtudes intelectuais e de escolher e agir segundo deliberação. Assim sendo, a mulher não dispõe das condições necessárias para cumprir a finalidade do ser humano, a saber, "fazer tudo com razão ou, pelo menos, não sem razão" (conforme Ética Nicomaqueia I 7 1098a7). Essa privação da vida racional à mulher a exclui, bem como exclui também o escravo, dentro do sistema aristotélico, do acesso à felicidade humana perfeita ou completa, visto que este bem supremo é uma atividade da alma segundo a virtude mais perfeita, a qual possui um vínculo intrinsecamente necessário com o exercício perfeito do uso deliberativo da razão. Disso segue-se, aos olhos de Aristóteles, que a mulher não pode encontrar sua finalidade específica na vida da pólis, encontrando aí a autarquia necessária a sua felicidade como é o caso do varão (marido, senhor e pai). Portanto, sendo a mulher sempre inferior ao homem, não há outra vida possível à mulher além da vida confinada ao lar (oikos) e a da obediência ao marido. Essa teoria parece conduzir a um conformismo descritivista da condição na qual a mulher encontrava-se imersa na Grécia antiga, a saber, excluída do exercício da cidadania tomada em seu sentido estrito e, ao mesmo tempo, remete a um prescritivismo conservador com consequências político-filosóficas nefastas na medida em que "legitima" a privação do seu acesso à cidadania e, 
consequentemente, a exclui do domínio propriamente humano. Um homem fora da pólis é, diz-nos Aristóteles, como uma parte ou um órgão apartado do corpo e, nesse sentido, é dito homem apenas por homonímia por semelhança: assim como uma mão decepada continua sendo dita 'mão' apenas por possuir ainda uma conformação externa semelhante à mão ligada ao corpo, o qual confere a ela a funcionalidade que lhe permite subsistir, ser definida e conhecida como algo específico. Com a aplicação da tese da anterioridade do todo frente às partes à explicação da relação entre os conceitos de cidadania e pólis, Aristóteles acredita estar fundamentando, do ponto de vista filosófico, uma crença bem compartilhada entre os gregos que foi cristalizada pelo ditado: "um homem, nenhum homem”, pois um homem isolado da comunidade política não pode viver como um homem, em sentido estrito, na medida em que não poderá atualizar as capacidades caracterizadoras da humanidade: o discurso, a persuasão, a deliberação, a decisão e a ação política enquanto atividades intrinsecamente vinculadas ao exercício pleno do uso deliberativo da razão. Uma vez que a mulher é incapaz de satisfazer as notas características do conceito de humanidade assim tomado, poderíamos dizer, seguindo o espírito do texto que, segundo Aristóteles, a mulher pode ser considerada um ser humano apenas em sentido frouxo ou derivado do termo não podendo, assim, participar daquelas atividades definidoras do cidadão, o único capaz de satisfazer os requisitos necessários (em que pese, sob a perspectiva aristotélica, não suficientes) à natureza humana: a administração da justiça (tribunais, julgamentos e decisões judiciais) e do governo (assembleia deliberativa, cargos deliberativos) ${ }^{14}$.

Aristóteles vai mais fundo na tentativa de embasar teoricamente seus preconceitos e elabora uma embriologia capaz de suportá-los. Nesse sentido, afirma, em Da geração animal I 18, que a concepção dá-se mediante a simbiose entre o esperma masculino e o líquido menstrual feminino. $\mathrm{O}$ esperma era considerado o elemento formal que punha o elemento material, o mênstruo, fornecido pela mulher, em movimento. Segundo Aristóteles, quando ocorria um predomínio pleno do elemento formal sobre o material, então, seria gerado um varão. Assim sendo, a geração de uma mulher já configura, para o filósofo, um primeiro grau de imperfeição, pelo fato da forma (que é princípio de determinação, atualidade e efetividade do ser, possuindo primazia ontológica total em relação à matéria, a qual é sinônimo de indeterminação, potencialidade e passividade) ser suplantada pela matéria. É visível, então, que a mulher é considerada um mero receptáculo de esperma e o homem o transmissor da forma e o introdutor do princípio anímico no embrião (conforme II 3 737a9), sendo a mulher, portanto, biologicamente inferior em relação ao homem. A explicação última dessa 
inferioridade biológica repousa sobre a tese da anterioridade do ato sobre a potência. $\mathrm{O}$ ato é anterior à potência segundo a natureza, o tempo, a definição e o conhecimento (conforme Metafísica $\times 8^{15}$ ). Ora, se o varão é identificado como o fornecedor do princípio de atualidade ao embrião e a mulher como fornecedora do princípio de potencialidade e passividade, ela é biologicamente e ontologicamente inferior a ele.

Contudo, mesmo a inferioridade feminina estando, aos olhos de Aristóteles, "tão bem fundamentada" dentro de seu sistema filosófico, o Estagirita afirma, em Política I 12 1259b23, que "o homem é mais talhado ao poder do que a mulher, e a relação superior-inferior é respectivamente permanente entre eles a menos que ocorram "exceções de ordem da natureza" ${ }^{\prime 16}$. Tais exceções são mencionadas por Aristóteles no contexto de sua crítica à vida matrimonial espartana (Política II 9 1269b12-37), visto que, em Esparta, a família desempenhava um papel quase nulo na vida do homem da classe dominante, o qual dedicavase inteiramente ao cumprimento dos deveres cívicos e militares, tendo, também, os costumes das mulheres espartanas fama de licenciosos entre os gregos. No que tange à ausência de vida familiar na classe dominante, Esparta assemelha-se ao sistema proposto por Platão (Jaeger, 2010, p.813-814). Parece que essas duas póleis oferecerem as condições para que as “exceções de ordem da natureza", das quais Aristóteles fala, realizem-se, já que nelas a mulher desempenha um papel político e não está totalmente submetida à força da inferioridade que lhe foi imposta nem suas ações estão circunscritas à esfera do lar.

Simone de Beauvoir (1976, vol. I, p.41) bem marca que Aristóteles (cuja embriologia sobreviveu durante toda a idade média e só veio a ser revista na era moderna) assim como outros filósofos e cientistas, tentou distinguir o papel dos sexos na reprodução através de “opiniões desprovidas de qualquer fundamento científico, as quais refletem apenas mitos sociais". Nessa mesma linha, podemos concluir que Aristóteles tentou deduzir teses de cunho biológico a partir da observação da condição (a)cultural da mulher tal como ela se apresentava, em geral, na Grécia. A tentativa de explicar porque as coisas nos aparecem do modo como elas nos aparecem é uma metodologia recorrente na investigação filosófica de Aristóteles. Nesse sentido, Aristóteles crê que é tarefa do filósofo explicar porque as mulheres são submissas, incultas, talhadas, antes, ao silêncio do que ao discurso e propensas mais a ouvir as paixões do que a razão. E, caso a sua essência ou natureza não seja tal qual ela nos aparece, cabe ao filósofo o ônus de mostrar porque, uma vez que ela não é assim, ela nos aparece assim. O Estagirita tomou, em relação à explicação do comportamento e da condição feminina, uma decisão filosófica mais cômoda e menos revisionista que a do seu mestre 
buscando "salvar as aparências" ou explicar o fenômeno da condição de submissão e incultura física e intelectual da mulher na Grécia antigo no sentido pejorativo da expressão na medida em que não se propôs a aventar outras causas explicativas para esse fenômeno tais como fatores acidentais relativos a costumes marcados pela opressão, sujeição e pela privação do acesso a condições iguais às masculinas de formação intelectual, moral, física, cultural. Esse mesmo comodismo parece marcar a análise do fenômeno da escravidão, pois o Estagirita não sugere que tais convicções poderiam não estar fundamentadas de modo inteiramente legítimo sob a perspectiva da própria natureza humana, mas que se fundamentavam sobre algo mais acidental do que isso: o modo mediante o qual escravos e mulheres eram tratados e as condições a que eram submetidos.

\section{A circunscrição da determinação substancial da mulher à família segundo os $\$ \$ 165-166$ da Filosofia do Direito de Hegel}

A legitimação da tese hegeliana que o caráter feminino não é dado à consideração do universal e nem provido de grandes dotes intelectuais e, por isso, a sua atuação deve restringir-se à vida familiar está fundamentada no modo mediante o qual o conceito de eticidade articula-se em sua determinação imediata, a família. O processo de desdobramento do conceito de eticidade, do qual a família configura o primeiro momento, constitui-se a partir da conciliação e união orgânica de indivíduos diferenciados que exercem funções complementares. Tal diferenciação existe também entre os sexos e é fundada na razão, a qual confere a essa diferenciação uma significação intelectual e ética. Assim sendo, a devoção exclusiva da mulher à família fundamenta-se, segundo Hegel, sobre razões profundas dadas pelo desenrolar do conceito de eticidade: na relação homem-mulher, aquele "é a espiritualidade que se desdobra, por um lado, na independência pessoal que existe por si e, por outro lado, se desdobra no saber e no querer da livre universalidade, na autoconsciência do pensamento conceitual e o querer do fím objetivo e último", enquanto essa "é a espiritualidade que se mantém na unidade como saber e querer do substancial na forma da individualidade concreta e sentimento". Segue-se disso, de maneira logicamente necessária, segundo o sistema hegeliano, não só como resultado de preconceitos morais datados e contingentes, que o homem, sendo uma espiritualidade poderosa e ativa com referência ao exterior, é naturalmente superior à mulher no que concerne às capacidades reflexivas necessárias à vida social e política, ao estudo da ciência e à luta com o mundo exterior e consigo mesmo, enquanto a mulher, sendo uma espiritualidade subjetiva e passiva, é superior 
ao homem no que diz respeito às capacidades requeridas pela subjetividade ética do sentimento. Faz-se claro, então, que, sob a perspectiva do filósofo alemão, as mulheres possuem um caráter naturalmente mais ligado ao sentimento, à submissão, à fraqueza e à incapacidade intelectual, agindo segundo opiniões e inclinações contingentes. Tais características imputadas, por Hegel, às mulheres conflagra a desigualdade delas em relação aos homens. A afirmação da inferioridade da mulher em relação ao homem e a impossibilidade dela ter acesso a direitos civis e políticos torna evidente que a relação de igualdade externa entre as famílias, tomadas enquanto "personalidades substanciais", não expressa uma relação de igualdade interna, a qual se era de esperar para que houvesse a concretização dos princípios universais da liberdade através do desenvolvimento dos direitos da pessoa para além das diferenças de sexo, o que faz com que, nesse caso, a liberdade perca espaço para uma forma de opressão.

No entanto, mesmo que o movimento argumentativo, no qual se afirma a inferioridade da mulher em relação ao homem e a sua exclusão da vida social e política, conjugue, de modo indissociável, preconceitos morais datados e necessidade lógica, o sistema hegeliano dispõe de uma noção que nos permite vislumbrar a possibilidade da igualdade civil e política entre homens e mulheres, a saber, o conceito de reposição ética do natural através da objetivação do espírito. A noção hegeliana de segunda natureza, tal como ela aparece nos $\S \S 142$ e 151, é engendrada mediante a objetivação que o espírito cumpre quando desenvolve sua natureza ética, a qual toma o lugar da primeira vontade meramente natural e, enquanto modo mais universal de agir, aparece como costume. Nessa segunda natureza, o espírito realiza, em seu desenvolvimento, uma natureza ética, na qual a liberdade assume a forma da necessidade, pois é em tal natureza que a realidade ética é, necessariamente, o mundo das relações comunitárias e da organicidade da liberdade. Tal realidade ética ou segunda natureza é, portanto, a história do movimento ativo dos indivíduos chegando à consciência de si mesmos como membros duma comunidade. A segunda natureza configura, assim, um processo de mediação daquilo que é imediato ou natural por meio da autoconsciência dos indivíduos, a qual penetra na totalidade dos costumes produzidos pela objetivação do espírito e faz com que o desdobramento da racionalidade opere transformações nas combinações entre o ético e o natural, as quais são processos constitutivos da tessitura dos elementos éticos. Tais transformações, operadas através da mediação do natural pela racionalidade ética, permitem o engendramento de novos costumes na medida em que os antigos não tornam mais possível aos indivíduos reconhecerem a si mesmos como membros de relações comunitárias 
perpassadas por eles.

Nesse sentido, Kervégan (1995, p.15) afirma que a relação que o espírito mantém com a natureza é de sucessão e oposição. A sucessão se dá porque ele é mais elevado que ela (Enciclopédia das ciências filosóficas §440) na medida em que ele corresponde ao retorno da ideia sobre si mesma a partir de sua exteriorização. A oposição se dá porque o espírito se opõe à natureza assim como a liberdade à necessidade, pois ele só alcança sua efetivação enquanto supera a natureza, isto é, enquanto é outro em relação a ela. Nesse sentido, o espírito tem a capacidade de constituir por si mesmo uma segunda natureza, o hábito, que lhe permite não ter somente uma liberdade abstrata, mas efetivada e objetivada graças às instituições da vida social, do direito positivo e do Estado. Portanto, ainda que a mulher pudesse ser tomada como naturalmente inferior ao homem sob algum aspecto, a noção de reposição ética do natural parece constituir uma alternativa interpretativa à desalentadora e preconceituosa defesa hegeliana da inferioridade das mulheres em relação aos homens e sua exclusão dos direitos civis e políticos, pois ela permite que a "propensão natural imediata" que as impede de participar da vida política e as confina à família, por exemplo, possa ser mediada e reposta pelos costumes. É importante notar que a letra do texto no qual Hegel se pronuncia especificamente sobre a natureza inferior da mulher parece ainda adotar uma posição muito próxima daquela defendida por Aristóteles. No entanto, acreditamos que estaria de acordo com o espírito de seu texto, assentado sobre sua letra acerca do conceito de "segunda natureza" como reposição ética do natural, que nada impede que a opressão que o homem exerce sobre a mulher seja necessária ou permanente em relação ao movimento de objetivação do espírito.

Nossa interpretação, aliás, poderia tornar a argumentação hegeliana provida de um antídoto, que o próprio Hegel parece não ter utilizado explicitamente para esse fim, capaz de torná-la imune àquilo que Wood (1990, p.93) chama de uma limitação concernente à coadunação de sua posição sobre a condição da mulher e dos escravos e sua adoção do princípio da sociedade moderna que prescreve que todos os seres humanos sejam considerados pessoas dotadas de direitos e liberdade. Nesse sentido, o único modo de fazer o argumento, que preconiza que não podemos efetivar o auto-reconhecimento ou a certeza de si a não ser enquanto membros de uma comunidade de pessoas livres que reconhecem mutuamente os direitos umas das outras, prescindir de qualquer premissa arbitrária será através da admissão da tese que o auto-reconhecimento implica, de necessidade, que se reconheça a todos, inclusive mulheres e escravos, como pessoas. Do contrário, poderia uma 
pessoa alcançar o reconhecimento e certeza de si através de uma não-pessoa?

$* * *$

Através dessa breve nota sobre as perspectivas platônica, aristotélica e hegeliana acerca da condição feminina e o lugar destinado às mulheres no interior do sistema político desses três filósofos, esperamos ter conseguido sugerir que o modo como eles articulam elementos descritivos e prescritivos na construção das categorias de análise de seus sistemas de filosofia política lhes permitem propor teses capazes de enfrentar melhor ou pior o problema da sujeição da mulher como um dos fatores que tornam o conceito de natureza humana, fundado sobre a exclusão de certos grupos de indivíduos por critérios arbitrários de sexo, gênero, cor, etnia, incapaz de alcançar o estatuto de plenamente universal.

Segundo nosso esboço, o sistema aristotélico parece ter sido o menos dotado de capacidade de superação desse problema na medida em que, pelo menos relativamente à análise da natureza e condição femininas, suas decisões filosóficas foram fortemente marcadas pela subordinação de elementos prescritivos a elementos descritivos. No entanto, o afã aristotélico de "salvar as aparências" de modo algum implica ou legitima que as mulheres ou os escravos devam ser tratados com vilania ou violência. Como sugere Martha Nussbaum (1995, p.122), qualquer modo aviltante de tratamento dirigido àqueles que Aristóteles considera dotados de uma natureza deficitária em relação ao paradigma da natureza e da função humanas não poderia ser deliberado, escolhido nem praticado pelo bom agente moral justamente na medida em que cabe ao prudente conduzir os menos dotados intelectualmente a levar a melhor vida possível dentro de suas intrínsecas limitações.

A tendência fortemente idealista de Platão, a qual o faz sempre privilegiar os elementos prescritivos em detrimentos dos descritivos, parece ter permitido ao filósofo ateniense ser o primeiro a conceder à mulher a sua inserção na esfera pública e dotá-la de deveres políticos e de igual acesso à formação física e intelectual destinada aos varões da classe dos guardiões da pólis. Tese que, como vimos, era considerada altamente revisionista em razão de seu caráter totalmente avesso ao lugar de confinamento ao oikos comumente destinado à mulher nas póleis gregas. No entanto, as pretensões platônicas não podem ser confundidas com uma consideração da mulher como portadora de virtudes intelectuais e morais que pudessem ser equiparáveis àquelas dos homens, mas devem ser lidas como estritamente vinculadas ao papel necessário que as mulheres devem cumprir para que sistema 
político de Platão possa funcionar.

Hegel, pareceu-nos transitar entre o descritivismo e prescritivismo na medida em que ora se aproxima de Aristóteles defendendo velhos preconceitos que descrevem, de alguma maneira, o modo como o fenômeno do comportamento feminino era observado também na era moderna, ora mostra-se fortemente revisionista ou "idealista", para usar a expressão cara a Kervégan (1995), na medida em que propõe que nenhuma "condição natural” alcança objetivação se não for revestida pela racionalidade intrínseca à eticidade dos costumes. Assim sendo, ainda que houvesse, sob a perspectiva hegeliana, algum motivo para se crer que a natureza das mulheres é, sob algum aspecto, inferior a dos homens, isso não impede que, por meio da reposição ética do natural, a mulher venha a ser dotada de uma segunda natureza na qual ela também possa se reconhecer e ser reconhecida. 


\section{Notas}

${ }^{1}$ Gostaria de agradecer ao Professor José Pinheiro Pertille do Departamento de Filosofia da UFRGS por me incentivar, mesmo que indiretamente e a distância, a desengavetar este texto cuja primeira versão redigi originalmente como trabalho de conclusão de um seminário de filosofia política, ministrado por ele, há mais de uma década. Agradeço também à minha colega Maria de Lourdes Alves Borges do Departamento de Filosofia da UFSC pela sororidade em tempos em que me fora difícil crer no "espírito absoluto", mas que, graças ao seu coleguismo, puderam ser transformados na necessidade de publicar um texto sobre feminismo.

${ }^{2}$ Prof. ${ }^{\text {a }}$ Dra. do Departamento de Filosofia da Universidade Federal de Santa Catarina (UFSC), Florianópolis, Brasil. E-mail: santos.marina@ufsc.br

3 Todas as citações da República utilizarão a tradução para a língua portuguesa de Maria Helena da Rocha Pereira (Platão,1985).

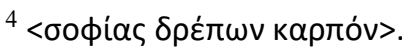

${ }^{5}$ Não é nosso objetivo aqui explorar ou refutar a tese das "aptidões naturais" nem identificar as razões que impediram Platão e Aristóteles de antever que mesmo que a tese das "aptidões naturais" pudesse ser aceita, elas não poderiam ser descobertas e desenvolvidas caso os cidadãos não desfrutassem de igual oportunidade de acesso às mais diversas atividades no interior da pólis.

${ }^{6}$ República IV 431b-c está imersa no contexto de análise da natureza e estruturação da comunidade dos guardiões que inicia na segunda metade do Livro II e se estende até o Livro V. Essa análise gravita em torno da questão da educação que deve ser assegurada à classe guardiã e de que a distribuição das tarefas que lhe cabem deve ser feita através da adoção de critérios ligados às virtudes dos guardiões. Platão compara a estruturação da cidade com a estruturação da alma humana notando que os elementos ou funções racionais da psyché humana devem governar o homem, assim, como os homens, cuja alma é governada pela razão e não se deixa subjugar e escravizar pelos prazeres e desejos sensíveis, devem governar os homens cujas almas são tiranizadas pelas inclinações sensíveis. Nesse sentido, Sócrates, em sua discussão com Glauco e Adimanto, afirma em 431b9-c3: "Ora, desejos prazeres e penas, em grande número e de todas as espécies, seria coisa fácil de encontrar,

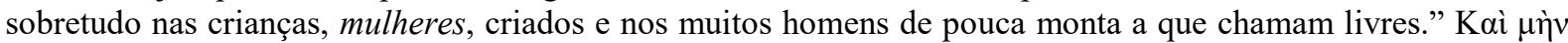

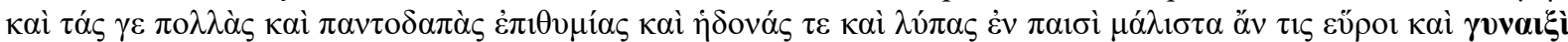

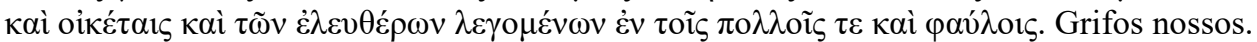

${ }^{7}$ República $\mathrm{V} 469 \mathrm{~d}$ situa-se no contexto de crítica à prática da rapina (para além das armas) junto aos cadáveres dos inimigos mortos em combate. Nesse contexto, Sócrates afirma, em 469d6-e2: "Não parece coisa baixa e gananciosa despojar um cadáver, e própria duma mulher e de quem tem pouco entendimento, considerar inimigo o corpo de um morto, quando o inimigo já se evolou, deixando ficar o invólucro com que combatia? Ou julgas que há alguma diferença entre a atitude destas pessoas e a dos cães, que se enfurecem com as pedras que lhes

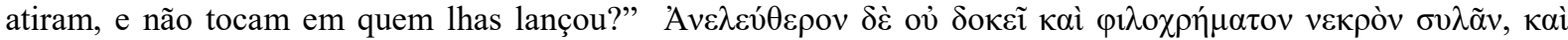

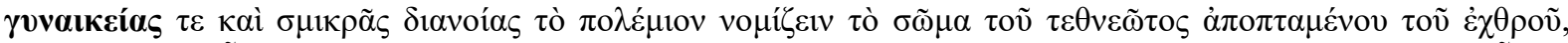

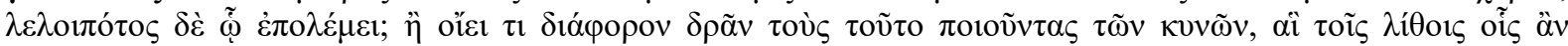

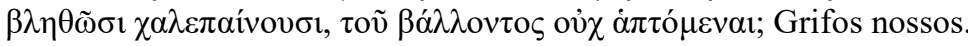

${ }^{8}$ República VIII 557c encontra-se no contexto de discussão das formas de governo e da transição da oligarquia à democracia. Nesse contexto, Sócrates afirma, ironicamente, na belíssima descrição platônica da forma democrática de governo, em 557c4-9: "Tal constituição é muito capaz de ser a mais bela das constituições. Tal como um manto de muitas cores, matizado com toda a espécie de tonalidades, também ela, matizada com toda a espécie de caracteres, apresentará o mais formoso aspecto. E talvez que, embevecidas pela variedade do colorido, tal como as crianças e as mulheres, muitas pessoas julguem esta forma de governo a mais bela."

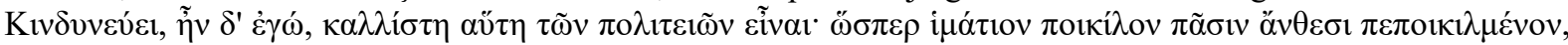

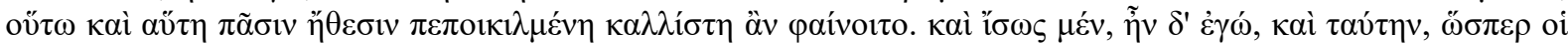

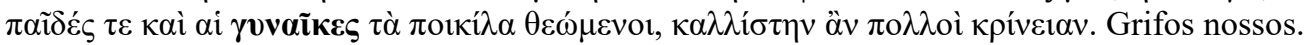

${ }^{9}$ República VIII 563b prossegue ainda com a discussão das formas degeneradas de governo, agora, analisando a transição da democracia à tirania. Nesse contexto, Sócrates afirma em 563b4-d1: "Mas o extremo excesso de liberdade, meu amigo, que aparece num Estado desses, é quando homens e mulheres comprados não são em nada menos livres do que os compradores. Mas por pouco me esquecia de dizer até que ponto vai a igualdade e liberdade nas relações das mulheres com os homens e destes com aquelas.". Ao que Glauco responde: "Então vamos, como Ésquilo, “dizer o que nos acudiu agora mesmo aos lábios"?. Sócrates, então, completa: 
"Absolutamente. Eu por mim vou falar dessa maneira. Efetivamente até que ponto os animais submetidos ao homem são mais livres aqui do que em qualquer outro sítio, é coisa que ninguém acreditaria sem o experimentar. É que as cadelas, conforme o provérbio, são como as donas e também os cavalos e burros andam pelas ruas, acostumados a uma liberdade completa e altiva, embatendo sempre em quem vier em sentido contrário, a menos que saiam do caminho; e tudo o mais é assim repleto de liberdade."

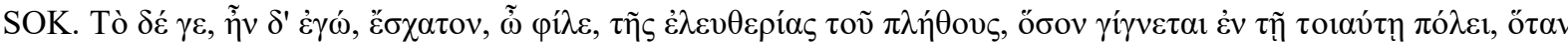

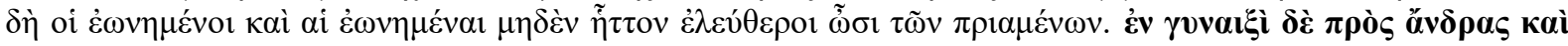

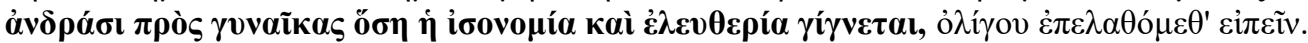

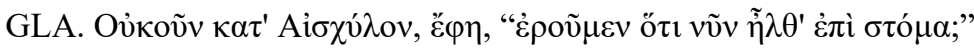

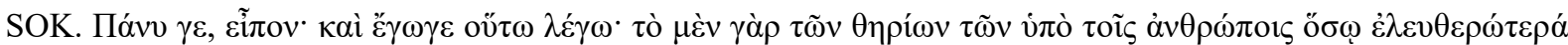

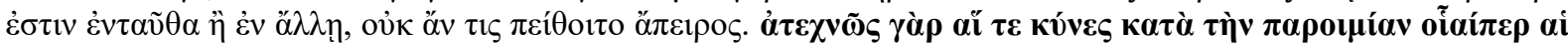

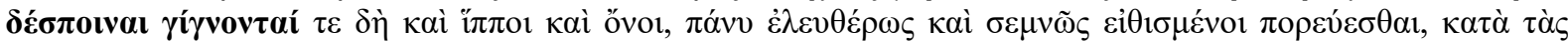

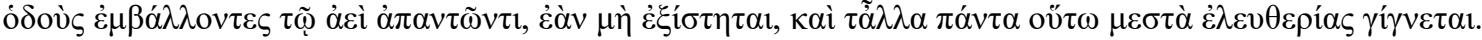

${ }^{10}$ Todas as citações da Política utilizarão a tradução para a língua portuguesa de António Campelo de Amaral e Carlos de Carvalho Gomes (Aristóteles, 1998).

${ }^{11}$ Todas as citações do De Anima seguirão a tradução para a língua inglesa de Hicks (Aristóteles, 1991).

${ }^{12}$ Para a distinção entre esfera pública e privada, ver Arendt (2001, p.33).

${ }^{13}$ Poderíamos pensar numa analogia de proporção para explicar tais passagens de Política I 5:

senhor, marido, pai : função racional da alma

escravo, mulher e filhos função irracional da alma

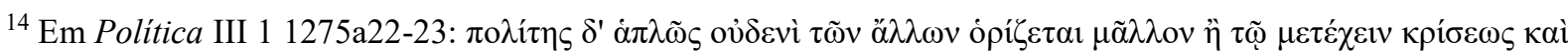
$\dot{\alpha} \rho \chi \tilde{\eta} s$.

${ }^{15}$ Para um breve esboço sobre os sentidos da prioridade do ato sobre a potência ver Dos Santos (2011).

${ }^{16}$ Sobre as dificuldades de tradução e interpretação dessa passagem, ver Newman (1991, Vol. II, p.210). 


\section{Referências bibliográficas}

ARENDT, H. A condição humana. Tradução de Roberto Raposo. Forense Universitária, Rio de Janeiro, $10^{\text {a }}$ edição, 2001.

ARISTOTE. L'Éthique à Nicomaque. Tradução, notas e comentários de R. Gauthier \& J. Jolif. 2 tomos. Peeters, Leuven, 2002.

ARISTÓTELES. Metafísica. [Edición trilingue por Valentín García Yebra]. Madrid, Gredos, 1998.

ARISTÓTELES. Politica. Tradução para a língua portuguesa de António Campelo de Amaral e Carlos de Carvalho Gomes, Vega, Lisboa, 1998.

ARISTOTLE. De Anima. Tradução de R. D. Hicks, Prometheus Books, New York, 1991.

ARISTOTLE. "Generation of animals". In: BARNES, J. (org.). The Complete Works of Aristotle. Princeton University Press, 1995, pp.1111-1218.

BEAUVOIR, S. Le Deuxième Sexe. (2 vol.) Gallimard, Paris, 1976.

DOS SANTOS, M. "Notas sobre a prova aristotélica do ato sobre a potência em Metafisica Theta 8". In: STORCK, A. \& ZILLIG, R. (Orgs). Aristóteles: Ensaios de Ética e Metafísica, Linus, Porto Alegre, 2011.

HEGEL, G. W. F. Enciclopédia das ciências filosóficas em epítome. 3 volumes. Tradução para a língua portuguesa de Artur Morão, Edições 70, Lisboa, 1989.

HEGEL, G. W. F. Principes de la philosophie du droit. Gallimard, Paris, 1989.

JAEGER, W. Paidéia: A formação do homem grego. Tradução de Artur Parreira. Martins Fontes, São Paulo, 2001.

KERVÉGAN, J. “Toute vraie philosophie est un idéalisme - L'esprit et ses 'natures' ”. In: MALER, H. (Org.). Hegel passé, Hegel à venir, Harmattan, Paris, 1995, pp. 11-28. 
NEWMAN, W. L. The politics of Aristotle. 4 Vol., Ayer Company, New Hampshire, 1991.

NUSSBAUM, M. "Aristotle on human nature and the foundations of ethics". In: ALTHAM, J. \& HARRISON, R. (Orgs.). World, Mind, and Ethics: Essays on the Ethical Philosophy of Bernard Williams, Cambridge, CUP, 1995, pp. 86-131.

PLATÃO. A República. Tradução para a língua portuguesa de Maria Helena da Rocha Pereira, Fundação Calouste Gulbenkian, Lisboa, 1985.

WOOD, A. Hegel's ethical thought. Cambridge, CUP, 1990. 